Brit. J. vener. Dis. (1960), 36, 40.

\title{
INCIDENCE OF TREPONEMAL DISEASE IN A GROUP OF IMMIGRANTS IN EAST LONDON*
}

\author{
BY \\ ERIC M. C. DUNLOP \\ The Whitechapel Clinic, The London Hospital
}

The object of this study was to determine the incidence of treponemal disease (syphilis or yaws) in a group of coloured immigrants who attended the Whitechapel Clinic of The London Hospital between November 1, 1957, and October 31, 1958. The incidence of untreated disease is compared with that found during the same period in white patients attending the department.

Table I shows the incidence of untreated treponemal disease separately for white and coloured men and women. All patients in whom treponemal disease had been previously diagnosed and treated were excluded, with the exception of those who gave a history of treatment for yaws in childhood.

TABLE I

COMPARATIVE INCIDENCE OF TREPONEMAL DISEASE, WHITECHAPEL CLINIC, NOVEMBER 1, 1957, TO OCTOBER 31, 1958

\begin{tabular}{c|c|c|c|c}
\hline \multirow{2}{*}{ Race } & \multirow{2}{*}{ Sex } & Total Attending & \multicolumn{2}{|c}{ Treponemal Disease } \\
\cline { 3 - 5 } & & & No. & per cent. \\
\cline { 2 - 5 } White & Male & 2,139 & 27 & $1 \cdot 3$ \\
& Female & 769 & 18 & $2 \cdot 3$ \\
\hline Coloured & Male & 729 & 44 & 6 \\
& Female & 127 & 42 & $33 \cdot 1$ \\
\hline
\end{tabular}

Of 2,139 white men, 27 (1.3 per cent.) had syphilis and in 769 white women the comparable figure was eighteen ( $2 \cdot 3$ per cent.). Of 729 coloured men, 44 ( 6 per cent.) were found to have treponemal infection and the comparable figure for 127 coloured women was 42 (33.1 per cent.). Fifteen of the 42 coloured women had been referred because of positive antenatal blood tests for syphilis. This raised the percentage of infected women and also underlines the continuing need for routine testing in pregnancy.

Paper read at General Assembly of I.U.V.D.T., London, October 14, 1959.
Table II shows that the bulk of treponemal disease in the coloured men was due to late syphilis or to yaws. Early syphilis occurred in 0.7 per cent. of white compared with 1.1 per cent. of coloured men, and in 1.6 per cent. of white compared with 2.4 per cent. of coloured women.

TABLE II

INCIDENCE OF EARLY AND LATE SYPHILIS

\begin{tabular}{|c|c|c|c|c|c|c|c|}
\hline \multirow{3}{*}{ Race } & \multirow{3}{*}{ Sex } & \multicolumn{6}{|c|}{ Syphilis } \\
\hline & & \multicolumn{2}{|c|}{ Early } & \multicolumn{2}{|c|}{ Late } & \multicolumn{2}{|c|}{ Total } \\
\hline & & No. & $\begin{array}{c}\text { Per } \\
\text { cent. }\end{array}$ & No. & $\begin{array}{c}\text { Per } \\
\text { cent. }\end{array}$ & No. & $\begin{array}{c}\text { Per } \\
\text { cent. }\end{array}$ \\
\hline White & $\begin{array}{c}\text { Male } \\
\text { Female }\end{array}$ & $\begin{array}{l}14 \\
12\end{array}$ & $\begin{array}{l}0.7 \\
1.6\end{array}$ & $\begin{array}{r}13 \\
6\end{array}$ & $\begin{array}{l}0.6 \\
0.8\end{array}$ & $\begin{array}{l}27 \\
18\end{array}$ & $\begin{array}{l}1 \cdot 3 \\
2 \cdot 3\end{array}$ \\
\hline Coloured & $\begin{array}{c}\text { Male } \\
\text { Female }\end{array}$ & $\begin{array}{l}8 \\
3\end{array}$ & $\begin{array}{l}1 \cdot 1 \\
2 \cdot 4\end{array}$ & $\begin{array}{l}36 \\
39\end{array}$ & $\begin{array}{r}4 \cdot 9 * \\
30 \cdot 7^{*}\end{array}$ & $\begin{array}{l}44 \\
42\end{array}$ & $\begin{array}{r}6 \cdot 0 \\
33 \cdot 1\end{array}$ \\
\hline Total & $\ldots$ & 37 & & 94 & & 131 & \\
\hline
\end{tabular}

*Including "syphilis or yaws".

While the total percentage of treponemal disease was nearly five times greater in this group of coloured men than in the white men, and fourteen times greater in coloured than in white women, there was less disparity in the incidence of early syphilis which was only rather less than twice as common in the coloured immigrants than in white patients.

Table III (opposite) shows that, of a total of 37 white and coloured patients suffering from early syphilis, 32 had acquired the disease in the United Kingdom and five, two of whom were coloured, had acquired it abroad. Although this group of immigrants had a high incidence of late treponemal disease brought with them from abroad, the majority of early infections had been acquired in the United Kingdom.

Table IV (opposite) shows that 82 of 86 infected immigrants came from the Caribbean zone, three from Pakistan, and one from Cyelon. 
TABLE III

EARLY SYPHILIS ACQUIRED IN U.K. OR ABROAD

\begin{tabular}{|c|c|c|c|c|}
\hline Race & Sex & U.K. & Abroad & Total \\
\hline White & $\begin{array}{l}\text { Male } \\
\text { Female }\end{array}$ & $\begin{array}{l}11 \\
12\end{array}$ & 3 & $\begin{array}{l}14 \\
12\end{array}$ \\
\hline Coloured & $\begin{array}{c}\text { Male } \\
\text { Female }\end{array}$ & $\begin{array}{l}6 \\
3\end{array}$ & 2 & $\begin{array}{l}8 \\
3\end{array}$ \\
\hline Total & . & 32 & 5 & 37 \\
\hline
\end{tabular}

TABLE IV

AREA OF ORIGIN OF INFECTED IMMIGRANTS

\begin{tabular}{c|c|c|c|c}
\hline Sex & Caribbean & Pakistan & Ceylon & Total \\
\hline Male & 40 & 3 & 1 & 44 \\
\hline Female & 42 & - & - & 42 \\
\hline Total .. & 82 & 3 & 1 & 86 \\
\hline
\end{tabular}

\section{INCIDENCE OF YAWS}

It was clear that the high incidence of treponemal infection in coloured immigrants was in part due to yaws, and an attempt was therefore made to define that part.

\section{Clinical Material}

All the coloured immigrants who attended during the year were reviewed with respect to treponemal infection, either treated or untreated. In this way a total incidence for this group was obtained. The only patients excluded from this study were those who attended specifically for the follow-up of treated treponemal disease.

Table $\mathrm{V}$ shows that, of 898 coloured immigrants studied, 767 (85.4 per cent.) were men, and that definite treponemal infection had been diagnosed in $82(10.7$ per cent.) of them up to the time of review. In the 131 women, definite treponemal infection had been diagnosed in $46(35 \cdot 1$ per cent.) by the time of review.

TABle V

COLOURED IMMIGRANTS

TOTAL INCIDENCE OF TREPONEMAL INFECTION

\begin{tabular}{|c|c|c|c|c|}
\hline Sex & $\ldots$ & Men & Women & Total \\
\hline No. of Patients & . & 767 & 131 & 898 \\
\hline Syphilis or Yaws & $\left\{\begin{array}{l}\text { No. } \\
\text { Per cent. }\end{array}\right.$ & $\begin{array}{c}82 \\
10 \cdot 7\end{array}$ & $\begin{array}{c}46 \\
35 \cdot 1\end{array}$ & $\begin{array}{c}128 \\
14 \cdot 3\end{array}$ \\
\hline
\end{tabular}

Area of Origin

The country of origin of these immigrants is shown in Table VI. There were 579 Caribbeans and definite treponemal infection had been diagnosed in a total of 105 (18 per cent.); however, clinical evidence of syphilis had occurred in only fourteen $(2 \cdot 4$ per cent.), an incidence very similar to that in the other groups. The 35 per cent. incidence of treponemal infection in immigrant women is partly responsible for the high incidence found in Caribbeans, for 129 of the 131 women came from that area. Altogether treponemal infection had been diagnosed in 14 per cent. of West Africans, 6 per cent. of Indians, 5 per cent. of Pakistanis, and 3.6 per cent. of other coloured patients.

TABle VI

AREA OF ORIGIN AND INCIDENCE OF TREPONEMAL DISEASE

\begin{tabular}{|c|c|c|c|c|c|c|}
\hline \multirow{2}{*}{\multicolumn{2}{|c|}{$\begin{array}{l}\text { Area of } \\
\text { Origin }\end{array}$}} & \multirow{2}{*}{$\begin{array}{l}\text { No. of } \\
\text { Patients }\end{array}$} & \multicolumn{2}{|c|}{$\begin{array}{l}\text { All Treponemal } \\
\text { Disease }\end{array}$} & \multirow{2}{*}{\multicolumn{2}{|c|}{$\begin{array}{l}\text { Syphilis } \\
\text { No. Per cent. }\end{array}$}} \\
\hline & & & No. & Per cent. & & \\
\hline $\begin{array}{l}\text { Caribbean } \\
\text { West Africa } \\
\text { India } \\
\text { Pakistan } \\
\text { Other Coloured }\end{array}$ & $\begin{array}{l}\ldots \\
\ldots \\
\cdots \\
\cdots \\
\ldots\end{array}$ & $\begin{array}{c}579^{*} \\
78 \\
82 \\
76 \\
83\end{array}$ & $\begin{array}{r}105 \\
11 \\
5 \\
4 \\
3\end{array}$ & $\begin{array}{r}18 \cdot 1 \\
14 \cdot 1 \\
6 \cdot 1 \\
5 \cdot 3 \\
3 \cdot 6\end{array}$ & $\begin{array}{r}14 \\
2 \\
3 \\
3 \\
1\end{array}$ & $\begin{array}{l}2 \cdot 4 \\
2 \cdot 6 \\
3 \cdot 7 \\
3 \cdot 9 \\
1 \cdot 2\end{array}$ \\
\hline
\end{tabular}

${ }^{*}$ Includes all the coloured women except for two West Africans.

\section{METHOD OF STUdY}

Patients were questioned and examined to elicit evidence of yaws and syphilis; investigations by $x$ ray and examination of the cerebrospinal fluid were carried out in some cases and serological tests for syphilis in all. In 155 cases, the treponemal immobilization test was performed. In a small number of cases historical data were inadequate due to language and other barriers.

The results of each investigation are given in Table VII.

TABle VII

RESULTS OF INVESTIGATIONS

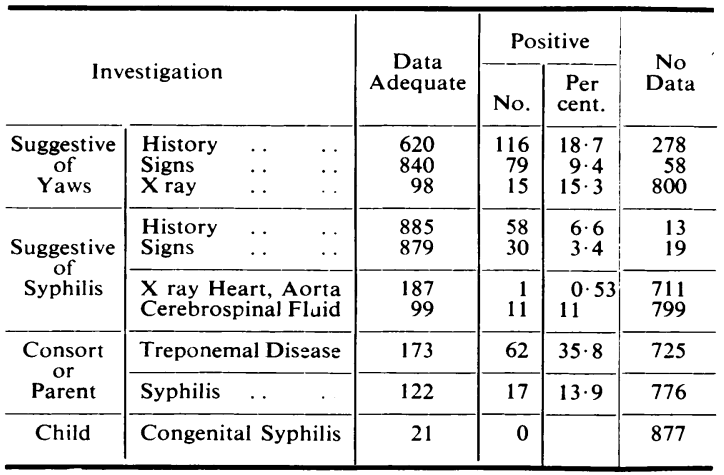

With regard to the history of yaws, information was adequate in 620 patients, of whom $116(18 \cdot 7$ per cent.) gave a history suggesting that condition. Of 840 patients examined adequately, $79(9 \cdot 4$ per cent.) had clinical signs suggestive of yaws, chiefly in the form of atrophic cutaneous scarring. Of 98 patients whose limbs were examined by $x$ ray for evidence of 
yaws, there were positive findings in fifteen. In fourteen it appeared that periostitis had occurred in childhood, and in the one remaining man aged 31 there was acute periostitis which was thought to be syphilitic. 58 (6.6 per cent.) of 885 patients gave a history suggesting syphilis and thirty (3.4 per cent.) of 879 patients had clinical evidence of that disease. $X$ ray examination of the heart and great vessels in 187 patients revealed one case of aortic aneurysm. The cerebrospinal fluid was examined as a diagnostic measure in 99 patients with treponemal infection, and evidence of neurosyphilis was found in eleven. In 62 (35.8 per cent.) of the 173 patients for whom the requisite data were available, a diagnosis of treponemal disease was made in a consort or parent. Similarly, in seventeen out of 122 patients, a parent or consort was found to have syphilis.

On the basis of this clinical differentiation it was possible to divide the patients into four groups (Table VIII):

(i) Those with evidence suggesting yaws (122).

(ii) Those with evidence suggesting syphilis (73).

(iii) Those with evidence suggesting yaws and syphilis (21).

(iv) The remainder (682).

TABLE VIII

INCIDENCE OF YAWS AND OF SYPHILIS

\begin{tabular}{|c|c|c|c|}
\hline \multirow[t]{2}{*}{ Group } & \multirow{2}{*}{$\begin{array}{l}\text { No. of } \\
\text { Patients }\end{array}$} & \multicolumn{2}{|c|}{$\begin{array}{l}\text { Treponemal Disease } \\
\text { Confirmed by Tests* }\end{array}$} \\
\hline & & No. & Per cent. \\
\hline $\begin{array}{l}\text { I. Yaws (Suggestive history, } \\
\text { signs, } x \text { ray) }\end{array}$ & 122 & 47 & $38 \cdot 5$ \\
\hline $\begin{array}{l}\text { II. Syphilis (Suggestive history, } \\
\text { signs, x ray, cerebrospinal } \\
\text { fluid, findings in contact } \\
\text { and family) }\end{array}$ & 73 & 26 & $35 \cdot 6$ \\
\hline III. Yaws + Syphilis & 21 & 10 & $47 \cdot 6$ \\
\hline IV. Remainder .. & 682 & 45 & $6 \cdot 6$ \\
\hline Total $\ldots$ & 898 & 128 & $14 \cdot 3$ \\
\hline
\end{tabular}

${ }^{*}$ Dark-field or S.T.S. (with T.P.I. in all latent cases and some others)

There were 122 patients in the "yaws" group and serological tests confirmed the clinical diagnosis in $47(38 \cdot 5$ per cent.) of them.

There were 73 in the "syphilis" group and serological tests or dark-field examination confirmed the diagnosis in 26 (35.6 per cent.). These 26 patients included ten with pathological changes in the cerebrospinal fluid. If it be accepted that yaws cannot cause neurological disease, this finding suggests that syphilis was responsible for a larger proportion of the 128 cases of treponemal infection than was clinically apparent.

There were 21 patients with evidence of both syphilis and yaws, and in ten ( 47.6 per cent.) sero- logical tests or dark-field examination enabled a firm diagnosis of treponemal disease to be made. Of these ten patients, all of whom had evidence of yaws in childhood, four were suffering from early syphilis, one had primary optic atrophy and a history of penile sore, and one had a positive Wassermann reaction in the cerebrospinal fluid. The other four patients all gave historical evidence to suggest syphilitic infection.

In the "remainder" of 682 patients with no clinical evidence of syphilis or yaws, 45 (6.6 per cent.) had serological evidence of infection confirmed by the treponemal immobilization test.

If historical evidence of yaws was considered alone, and all patients with evidence suggesting syphilis were excluded, then 36 ( 36 per cent.) of 101 patients with a positive history had treponemal disease confirmed by tests, compared with 46 (10 per cent.) of 448 with negative history and ten (4 per cent.) of 255 for whom historical data were inadequate.

\section{Summary AND CoNClusions}

The incidence of untreated treponemal disease was determined in 856 coloured immigrants who attended the Whitechapel Clinic of The London Hospital between November 1, 1957, and October 31, 1958; this was compared with that in 2,908 white patients. For men the incidence was 6 per cent. in immigrants compared with 1.3 per cent. For women, it was $33 \cdot 1$ per cent. in immigrants, compared with $2 \cdot 3$ per cent. The incidence of early syphilis for men was $1 \cdot 1$ per cent. in immigrants compared with 0.7 per cent.; for women it was 2.4 per cent. in immigrants compared with 1.6 per cent.

This group of coloured immigrants brought little early syphilis into the United Kingdom; 32 of the total of 37 coloured immigrants and white patients suffering from early syphilis acquired their infections within the United Kingdom.

A less selected group of coloured immigrants was studied further to determine the total incidence of definite treponemal infection and the relative incidence of yaws as compared with syphilis; only patients specifically attending for follow-up of treated treponemal infection were excluded from this group. Treponemal disease had been diagnosed in $128(14 \cdot 3$ per cent.) of 898 patients. In 47 of these 128 cases, there was evidence that the infection was due to yaws, in 26 that it was due to syphilis, and in ten that it was due to both yaws and syphilis. In 45 cases there was no evidence other than positive serological tests to suggest either condition.

It was clear that the absolute differentiation of syphilis and yaws in this group of immigrants was often impossible. The fact that tests of the cerebro- 
spinal fluid were positive in ten out of the 26 patients in the syphilis group, suggests that that disease was responsible for a higher proportion of the 128 cases of definite treponemal infection than was clinically apparent. There was evidence that infectious syphilis occurred in patients who had suffered from yaws.

Full investigation and treatment was clearly required in every case of treponemal infection.

I thank my clinical colleagues, and the office and laboratory staff, whose co-operation has made this study possible. I am most grateful to Mr. J. Myson, A.M.R., and the Staff of the Records Department, The London Hospital, for help in the coding and analysis of data.

\section{Fréquence de la tréponématose dans un groupe d'immigrants dans la partie est de Londres \\ Résumé}

On détermina la fréquence de la tréponématose non-traitée chez 856 immigrants de couleur vus à la clinique de Whitechapel du London Hospital entre le 1-er novembre 1957 et le 31 octobre 1958; on compara cette fréquence à celle chez 2.908 malades de race blanche. Pour les hommes, la fréquence fut de $6 \%$ parmi les immigrants et de $1,3 \%$ parmi les autres. Pour les femmes, elle fut de $33,1 \%$ et de $2,3 \%$ respectivement. La fréquence de la syphilis primaire fut de $1,1 \%$ pour les hommes de couleur et de $0.7 \%$ pour les blancs; pour les femmes, la proportion fut de $2,4 \%$ et de $1,6 \%$ respectivement.

Peu d'immigrants de couleur de ce groupe avaient apporté la syphilis primaire au Royaume Uni; 32 sur 37 immigrants de couleur et malades blancs atteints de syphilis primaire acquirent leurs infections au Royaume Uni.

En plus, un groupe moins homogène d'immigrants de couleur fut étudié pour déterminer la fréquence totale de l'infection confirmée au tréponème et la fréquence relative du pian par rapport à la syphilis; des malades suivis spécifiquement en raison de leur tréponématose traitée furent exclus de ce groupe. Sur 898 cas, la tréponématose fut décelée chez $128(14,3 \%)$ d'entre eux. Parmi ces 128 cas, l'infection était due au pian dans 47 cas, à la syphilis dans 26 cas et dans dix cas on a trouvé des signes de tous les deux. En 45 cas une réaction sérologique positive seule indiquait la présence de la maladie.

Il est clair que dans ce groupe d'immigrants il était souvent impossible de différencier d'une manière certaine entre le pian et la syphilis. Des réactions positives du liquide céphalo-rachidien chez dix malades sur 26 du groupe syphilitique semblent indiquer que la syphilis serait responsable d'une plus grande proportion des 128 cas de tréponématose confirmée que celle fournie par l'observation clinique. On a trouvé des preuves d'infection syphilitique survenant chez des malades atteints de pian.

Chaque cas de tréponématose exigeait, naturellement, un examen et traitement complets. 